\title{
Microbial adherence to vulvar epithelial cells
}

\author{
D. J. BIBEL, R. ALY, L. LAHTI, H. R. SHINEFIELD and H. I. MAIBACH
}

Department of Dermatology, University of California and Department of Pediatrics, Kaiser Foundation Hospital, San Francisco, California 94143, USA

\begin{abstract}
Summary. Under uniform experimental conditions, different degrees of selective attachment of Staphylococcus aureus and Candida albicans to epithelial cells of the labium majus, the labium minus, and the vagina were compared and contrasted with those found in studies with cells of the buccal and nasal mucosa and forearm skin by a novel analysis of adherence density. For both micro-organisms, the larger, rougher cells of the labium majus gave the highest adherence scores matched only by the interaction of $S$. aureus with fully keratinised nasal epithelial cells. Increasing acidity to $p \mathrm{H} 3.5$ enhanced microbial adherence to vaginal cells. Menstruation also influenced attachment; highest densities were reached between the third and fourth weeks of the cycle. Autogenous ribitol teichoic acid was found to block the attachment of $S$. aureus to labium majus and labium minus cells by $76 \%$ and $81 \%$ respectively, and to vaginal cells by $66 \%$. Adherence is considered to be an important attribute of vulvar ecology and may be a determinant of infectious disease.
\end{abstract}

\section{Introduction}

The specific attachment of bacteria and fungi to surface epithelial cells of the host is well documented (Gibbons and Van Houte, 1975; Beachey, 1980); investigators are now determining the possible functions of adhesion in various microbial ecosystems of the body (Bibel et al., 1983; Beachey et al., 1983; Freter and Jones, 1983). The characteristics of cellular interaction differ for a given microorganism or host tissue. The molecular basis of this specificity varies widely, and a micro-organism may possess more than one type of adhesin for coupling with complementary receptors (Woods et al., 1980; Bibel et al., 1982).

Of the body regions thus far examined for adherence, the vulva has been characterised least satisfactorily. The vulva has an especially complex ecology related to several distinct tissues and influenced by hormonal cycles. Adherence studies have been limited to the vagina (Mårdh and Weström, 1976; Botta, 1979; Sobel et al., 1981 $a$ and $b$ ), and investigations of the microbiology of the labia, particularly the labium majus, are rare (Aly et al., 1979).

This report, focusing on the labium majus, labium minus, and vagina, demonstrates the features of microbial adherence unique to this genital

Received 10 Feb. 1986; revised version accepted 5 Jun. 1986.

* Correspondence should be sent to Professor R. Aly, Department of Dermatology, University of California, San Francisco, CA 94143, USA. area. As observed in the mouth (Gibbons and Van Houte, 1975), adjacent anatomical structures differ in adherence capability; this explains in part their carriage of particular normal flora and resistance to pathogens.

\section{Materials and methods}

\section{Micro-organisms}

Staphylococcus aureus strain 502A, Candida albicans isolate 57409, Escherichia coli, Acinetobacter calcoaceticus, Pseudomonas aeruginosa, Streptococcus pyogenes, and an unidentified cutaneous $\alpha$-haemolytic streptococcus were grown in Tryptic Soy Broth (TSB; Difco) at $37^{\circ} \mathrm{C}$ for $18 \mathrm{~h}$. All of these micro-organisms had been subcultured in the laboratory at least ten times. Before adherence testing, the micro-organisms were centrifuged in two changes of buffer (usually $0.067 \mathrm{M}$ phosphate-buffered saline, PBS; $p \mathrm{H} \mathrm{6.8).} \mathrm{In} \mathrm{one} \mathrm{comparative} \mathrm{experiment,} S$. aureus was grown in Brain-Heart Infusion broth (BHI) and in MR-VP broth (Difco).

\section{Volunteers}

Seven healthy women between 22 and 40 years old gave their informed consent to these studies. They were not nasal carriers of $S$. aureus, but the labia majora of two subjects appeared to be colonised by this bacterium for the 2-month period of our observations. None was using oral contraceptives. Vaginal $p \mathrm{H}$ was determined by paper-strip indicator. 


\section{Epithelial cells}

Cells from the mid-labium majus, labium minus, vagina, and buccal and nasal mucosa, harvested by scraping with moistened wood spatulas, were dispersed in $2 \mathrm{ml}$ of buffer (PBS at $p \mathrm{H} 6.8$ or, for vaginal cells, $0.1 \mathrm{M}$ citric acid-phosphate, $p \mathrm{H} \mathrm{3.5)}$ and washed by filtration on a 10- $\mu \mathrm{m}$ pore-size filter (Mitex Millipore; Aly et al., 1977). Volar forearm cells were collected by the detergent-scrub method (Williamson and Kligman, 1965). In this procedure, a circular sterile aluminium ring $\left(4 \cdot 15 \mathrm{~cm}^{2}\right)$ is held against the tissue to retain $1 \mathrm{ml}$ of $0.075 \mathrm{M}$ phosphate buffer, $p \mathrm{H} 7 \cdot 9$, with Triton X-100 0.1\%. After scraping for 1 min with a Teflon scrubber "policeman", the dislodged cells are obtained with a pipette and washed as above. In later studies, we found that buccal and vaginal cells, because of their larger size that impedes filtration, could be more efficiently washed by centrifugation (twice in equal volumes of buffer). We pooled two or three samples of buccal, forearm, nasal, and labial cells; vaginal specimens were tested singly. Subjects donated no more than one sample of a given tissue per week.

\section{Adherence testing}

One $\mathrm{ml}$ of a microbial suspension containing $10^{7}-10^{8}$ $\mathrm{cfu} / \mathrm{ml}$ was mixed with $1 \mathrm{ml}$ of host epithelial-cell suspension and incubated for $90 \mathrm{~min}$ at $37^{\circ} \mathrm{C}$ in a shaking water bath (Aly et al., 1977). Bacterial suspensions were then washed by membrane (Millipore) filtration, but candida-cell mixtures were more effectively separated by dilution in buffer. Smears of the test suspensions on glass slides were fixed by heat and stained with crystal violet. By microscopy, we tallied the number of adhering microorganisms on each of 18-21 cells/class and calculated the average.

In later studies, we used a micrometer eyepiece to measure the size of at least 20 epithelial cells and counted their respective adhering micro-organisms; we then calculated the average density of adherence. Because the various host cells differ in area, especially between classes, a standard of comparison was thereby provided. Adherence scores were analysed by Student's $t$ test.

\section{Teichoic acid blockage of adherence}

Using our previously described procedures (Aly et al., 1980; Bibel et al., 1982) we tested the ability of staphylococcal ribitol teichoic acid to prevent the attachment of subsequently added $S$. aureus to vulvar epithelial cells. Briefly, a suspension of host cells and teichoic acid $2 \mathrm{mg} /$ $\mathrm{ml}$ was incubated at $37^{\circ} \mathrm{C}$ for $90 \mathrm{~min}$. S. aureus was then added and the tubes were again incubated for $90 \mathrm{~min}$. The preparations were washed and observed as above. We evaluated scores by comparing them with those for tests with untreated cells. Labium majus cells were tested in

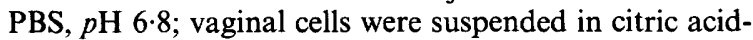
phosphate buffer, $p \mathrm{H} 3 \cdot 5$.

\section{Results}

Two general types of cells from the labium majus could be distinguished: those of medium size with smooth texture and fairly even perimeter and those of large size, rough consistency, and irregular shape. Small fragments of the larger keratinised cells were plentiful but were not scored. Transitional cells were also common, making differentiation difficult; the stage of enucleation was not a helpful index.

Staphylococcal adherence was tested simultaneously with labium majus and nasal cells. In a preliminary study, labial cells from two $S$. aureus nasal carriers and two non-carriers were also compared. The nasal cell system, being well characterised and familiar (Aly et al., 1977; Bibel et al., 1982), served as an inoculum and buffer control. In all five tests, adherence differed significantly between labial cell types $(\mathrm{p}<0.001)$ and their nasal-cell equivalent (upper granular and fully keratinised layers, $\mathrm{p}<0.001$ and $\mathrm{p}<0.001$ ). Adherence scores on medium and large labial cells averaged respectively $72 \%$ and $63 \%$ less than those of nasal cells. No significant differences were found in adherence of $S$. aureus to labial cells of nasal carriers and noncarriers.

Table I, listing the average population of given micro-organisms per labial cell, demonstrates the superior adherence of $S$. aureus. Streptococci attained intermediate levels, $40-50 \%$ of staphylococcal counts. $C$. albicans adherence was poor. $E$. coli did not attach to this tissue. Uninoculated control preparations of labium majus, labium minus, and vaginal cells displayed an average background of less than three staphylococci (range 0.3-3.05) and no candida organisms per cell.

TSB has been the routine culture medium. The effect of medium on adherence was ascertained by

Table I. Adherence of various micro-organisms to labium majus cells

\begin{tabular}{lrr}
\hline \multirow{2}{*}{\multicolumn{1}{c}{ Micro-organism }} & \multicolumn{2}{c}{ Index of adherence* } \\
\cline { 2 - 3 } & \multicolumn{1}{c}{$\begin{array}{c}\text { Medium, } \\
\text { smooth cell }\end{array}$} & $\begin{array}{c}\text { Large, } \\
\text { rough cell }\end{array}$ \\
\hline S. aureus & $47 \cdot 28 \pm 14 \cdot 52$ & $85 \cdot 03 \pm 22 \cdot 35$ \\
Str. pyogenes & $23 \cdot 20 \pm 9 \cdot 29$ & $37 \cdot 20 \pm 8 \cdot 36$ \\
$\alpha$-haemolytic streptococcus & $24 \cdot 56 \pm 14 \cdot 13$ & $28 \cdot 89 \pm 12 \cdot 57$ \\
E. coli & $1 \cdot 11 \pm 1 \cdot 36$ & $1 \cdot 14 \pm 1 \cdot 21$ \\
$P$. aeruginosa & $16 \cdot 58 \pm 7 \cdot 41$ & $28 \cdot 17 \pm 19 \cdot 20$ \\
A. calcoaceticus & $8 \cdot 21 \pm 6.53$ & $11 \cdot 43 \pm 6.61$ \\
C. albicans & $9 \cdot 31 \pm 4 \cdot 87$ & $24 \cdot 54 \pm 9 \cdot 03$ \\
& & \\
\hline
\end{tabular}

* Number of micro-organisms per cell of stated type expressed as mean of $18-21$ cells \pm SD. 
Table II. Comparison of $S$. aureus adherence to various epithelial cells*

\begin{tabular}{|c|c|c|c|}
\hline $\begin{array}{l}\text { Cell source } \\
\text { and type }\end{array}$ & Area $\left(\mu \mathrm{m}^{2}\right) \dagger$ & Number of cocci & Density $\ddagger$ \\
\hline $\begin{array}{l}\text { Nose } \\
\text { spinous } \\
\text { low granular } \\
\text { high granular } \\
\text { keratinised }\end{array}$ & $\begin{array}{r}294 \cdot 7 \pm 105 \cdot 3 \\
541 \cdot 9 \pm 140 \cdot 2 \\
882 \cdot 3 \pm 129 \cdot 6 \\
1095 \cdot 0 \pm 217 \cdot 3\end{array}$ & $\begin{array}{r}4 \cdot 70 \pm 3 \cdot 83 \\
18 \cdot 70 \pm 4 \cdot 45 \\
59 \cdot 67 \pm 14 \cdot 86 \\
119 \cdot 73 \pm 31 \cdot 10\end{array}$ & $\begin{array}{l}0.019 \pm 0.016 \\
0.037 \pm 0.015 \\
0.068 \pm 0.017 \\
0.113 \pm 0.036\end{array}$ \\
\hline $\begin{array}{l}\text { Forearm } \\
\text { Buccal mucosa } \\
\text { Labium majus } \\
\text { medium, smooth } \\
\text { large, rough }\end{array}$ & $\begin{array}{r}1196 \cdot 7 \pm 340 \cdot 9 \\
2075 \cdot 3 \pm 640 \cdot 9 \\
708 \cdot 5 \pm 276 \cdot 9 \\
832 \cdot 5 \pm 345 \cdot 8\end{array}$ & $\begin{array}{l}29 \cdot 87 \pm 14 \cdot 19 \\
63 \cdot 27 \pm 28 \cdot 29 \\
37 \cdot 47 \pm 9 \cdot 78 \\
87 \cdot 75 \pm 28 \cdot 00\end{array}$ & $\begin{array}{l}0.026 \pm 0.012 \\
0.031 \pm 0.013 \\
0.059 \pm 0.026 \\
0.119 \pm 0.052\end{array}$ \\
\hline $\begin{array}{l}\text { Labium minus } \\
\text { Vagina }\end{array}$ & $\begin{array}{l}1468 \cdot 2 \pm 351 \cdot 6 \\
1406.2 \pm 575.5\end{array}$ & $\begin{array}{l}20 \cdot 26 \pm 7 \cdot 34 \\
13 \cdot 10 \pm 7 \cdot 68\end{array}$ & $\begin{array}{l}0.015 \pm 0.001 \\
0.011 \pm 0.009\end{array}$ \\
\hline
\end{tabular}

* Standard buffer: 0.067 м PBS, $p \mathrm{H} \mathrm{6.8.}$

$\dagger$ Mean of 20 cells \pm SD.

$\ddagger$ Cocci $/ \mu \mathrm{m}^{2}$, calculated per cell then averaged.

Table III. Comparison of $C$. albicans adherence to various epithelial cells*

\begin{tabular}{|c|c|c|c|}
\hline $\begin{array}{l}\text { Cell source } \\
\text { and type }\end{array}$ & Area $\left(\mu \mathrm{m}^{2}\right) \dagger$ & $\begin{array}{l}\text { Number of } \\
\text { candida cells }\end{array}$ & Density + \\
\hline $\begin{array}{l}\text { Nose } \\
\text { spinous } \\
\text { low granular } \\
\text { high granular } \\
\text { keratinised }\end{array}$ & $\begin{array}{r}249 \cdot 1 \pm 179 \cdot 3 \\
526 \cdot 7 \pm 137 \cdot 5 \\
900 \cdot 0 \pm 138 \cdot 9 \\
1051 \cdot 1 \pm 94 \cdot 4\end{array}$ & $\begin{array}{l}0.78 \pm 0.83 \\
2.33 \pm 2.12 \\
1.56 \pm 1.33 \\
2.67 \pm 1.66\end{array}$ & $\begin{array}{l}0.0035 \pm 0.0049 \\
0.0048 \pm 0.0048 \\
0.0018 \pm 0.0015 \\
0.0025 \pm 0.0014\end{array}$ \\
\hline $\begin{array}{l}\text { Forearm } \\
\text { Buccal mucosa } \\
\text { Labium majus } \\
\text { medium, smooth } \\
\text { large, rough }\end{array}$ & $\begin{array}{r}1203 \cdot 0 \pm 333 \cdot 2 \\
2480 \cdot 0 \pm 481 \cdot 9 \\
756 \cdot 2 \pm 248 \cdot 7 \\
855 \cdot 8 \pm 312 \cdot 7\end{array}$ & $\begin{array}{r}5 \cdot 50 \pm 3.56 \\
13 \cdot 65 \pm 4 \cdot 67 \\
9 \cdot 31 \pm 4 \cdot 87 \\
24 \cdot 54 \pm 9.03\end{array}$ & $\begin{array}{l}0.0046 \pm 0.0021 \\
0.0056 \pm 0.0018 \\
\\
0.0129 \pm 0.0075 \\
0.0305 \pm 0.0134\end{array}$ \\
\hline $\begin{array}{l}\text { Labium minus } \\
\text { Vagina }\end{array}$ & $\begin{array}{l}1364 \cdot 8 \pm 254 \cdot 7 \\
1512 \cdot 1 \pm 200 \cdot 2\end{array}$ & $\begin{array}{l}6.80 \pm 2.58 \\
9 \cdot 50 \pm 4.87\end{array}$ & $\begin{array}{l}0.0049 \pm 0.0009 \\
0.0065 \pm 0.0036\end{array}$ \\
\hline
\end{tabular}

* Standard buffer: 0.067 м PBS, $p \mathrm{H} 6.8$.

$\dagger$ Mean of 20 cells \pm SD.

$\ddagger$ Candida cells $/ \mu \mathrm{m}^{2}$, calculated per cell then averaged.

growing $S$. aureus in simple MR-VP broth (consisting of peptone, dextrose, and phosphate) and in complex broth (BHI). Recentrifuged in buffer, the staphylococci from BHI broth did not form a pellet like those from MR-VP broth. Instead, the bacteria clung to the side of the test tube but were easily dispersed. They adhered twice as well as staphylococci grown in MR-VP broth $(\mathrm{p}<0.001$ for both types of labial cell). BHI broth cultures gave the same adhesion scores as organisms grown in TSB.
Table II compares the average cellular area, tally of attached $S$. aureus, and calculated density of adherence of various epithelial cells. The largest cells examined were from the buccal mucosa, but the density of attached staphylococci, despite their moderately large number, was similar to our findings with forearm and lower granular layer nasal cells. Fully keratinised nasal cells and the large, rough cells of the labium majus had superior and nearly equivalent adherence characteristics respect- 


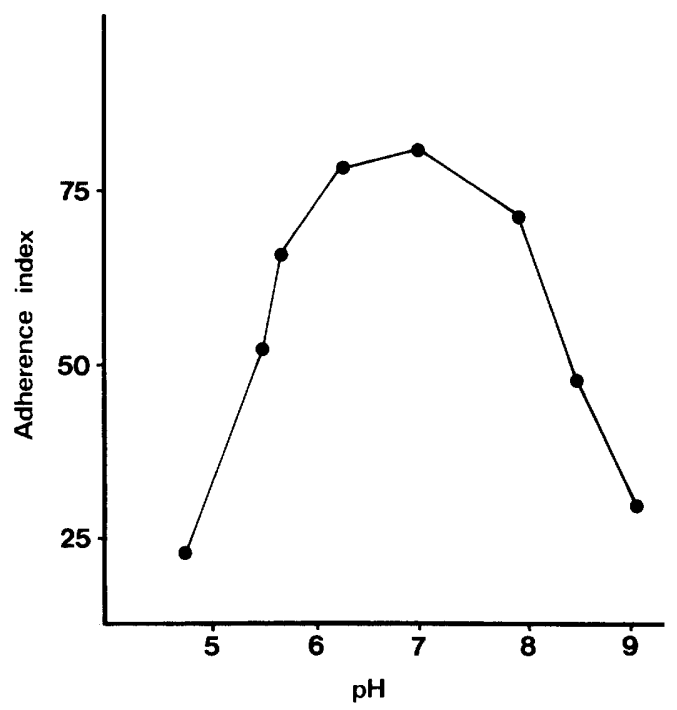

Fig. 1. Effect of $p \mathrm{H}$ on adherence of $S$. aureus to nasal cells. Average number of staphylococci per cell. See Methods.

ively. The densities of $S$. aureus on labium minus and vaginal cells were the lowest of the group.

Table III similarly summarises the variation in cell-candida coupling. In repeated experiments with two isolates of the micro-organism that differed in virulence, $C$. albicans failed to attach to nasal cells and clung poorly to forearm and labium minus cells. Cells of the labium majus, however, generally supported colonisation. In scores but not in calculated density, vaginal cells provided the same degree of adherence as the smaller cells of the labium majus.

The vagina presented two unique ecological variables: variation in hydrogen ion concentration and menstruation-related cellular changes. Routine adherence testing was done with buffers at $p \mathrm{H} 6.8$, in accordance with results from our early studies on nasal cells (fig. 1). This acidity reflects normal invivo conditions on buccal mucosa also, and is compatible with the environment of labial and forearm cells. (The skin environment is moderately acidic, $p \mathrm{H} c$. 5.5.) Adherence indices of $S$. aureus on labium majus cells tested at $p \mathrm{H} 5.5$ and 6.8 were nearly identical. However, the healthy vagina had a $p \mathrm{H}$ of 4.0-4.7 during the 4-week sampling period; the standard test at $p \mathrm{H} 6.8$, although useful for cellular comparison, proved suboptimal for adherence.

Figs. 2 and 3 show the improved attachment of $C$. albicans and especially $S$. aureus to vaginal cells in increasingly acidic buffers. Centrifugation of these micro-organisms in buffer at $p \mathrm{H}<5.0$ produced a thin layer of organisms against the test tube wall
Table IV. Blockage of labium majus and vaginal cell receptors to $S$. aureus by ribitol teichoic acid

\begin{tabular}{|c|c|c|c|}
\hline \multirow{2}{*}{$\begin{array}{l}\text { Cell source } \\
\text { and type }\end{array}$} & \multicolumn{2}{|c|}{$\begin{array}{c}\text { Number of } \\
\text { adherent cocci/cell }\end{array}$} & \multirow{2}{*}{$\begin{array}{l}\text { Signifi- } \\
\text { cance }\end{array}$} \\
\hline & Treated & Untreated & \\
\hline \multicolumn{4}{|l|}{ Labium majus* } \\
\hline Medium, smooth & $11 \cdot 47 \pm 10 \cdot 12 \ddagger$ & $48 \cdot 14 \pm 11 \cdot 52$ & $\mathrm{p}<0.001$ \\
\hline Large, rough & $16 \cdot 48 \pm 11 \cdot 37$ & $87 \cdot 38 \pm 16 \cdot 79$ & $\mathrm{p}<0.001$ \\
\hline Vagina $\uparrow$ & $8 \cdot 70 \pm 3 \cdot 21$ & $25.43 \pm 6.08$ & $\mathrm{p}<0.001$ \\
\hline
\end{tabular}

* Phosphate-buffered saline, $p \mathrm{H} 6 \cdot 8$.

$\uparrow$ Citrate-phosphate buffer, $p \mathrm{H} 3 \cdot 5$.

$\ddagger$ Mean \pm SD of 20 cells.

rather than the usual pellet; dispersion, nevertheless, was easily attained with a vortex mixer. When subjects were examined individually, or as a group after individual mean base levels were in effect standardised, differences in adherence scores for both $C$. albicans and $S$. aureus between $p \mathrm{H} 6.8$ and 3.5 were significant $(0.001<\mathrm{p}<0.005)$. These graphs further show that menstruation also affects adherence. The extent of this influence and the ranking of microbial densities by week varied among the individuals. Averaged data suggest that highest levels are reached between the third and fourth weeks of the cycle and that vaginal cells collected during the first or second week give the lowest densities for each of the test microorganisms. The plots of $S$. aureus cover a broader range than those of $C$. albicans and show greater weekly and individual differences.

We previously demonstrated that autogenous ribitol teichoic acid could partially block (65\% reduction) the attachment of $S$. aureus to fully keratinised nasal cells, suggesting that the wall component is an adhesin for these host cells. Table IV shows that bacterial receptors on the two types of cell of the labium majus, and on vaginal cells were also blocked in this way with reductions of $76 \%$, $81 \%$, and $66 \%$ respectively.

\section{Discussion}

Vulvar skin supports a unique microbial flora. This warm and moist region is composed of various specialised epithelia whose micro-environments and associated microbiota are influenced by the successive folds of protective tissue. Assorted facultative, microaerophilic and anaerobic grampositive and gram-negative bacteria are sheltered in the vagina (see Bartlett et al., 1977) whereas the 


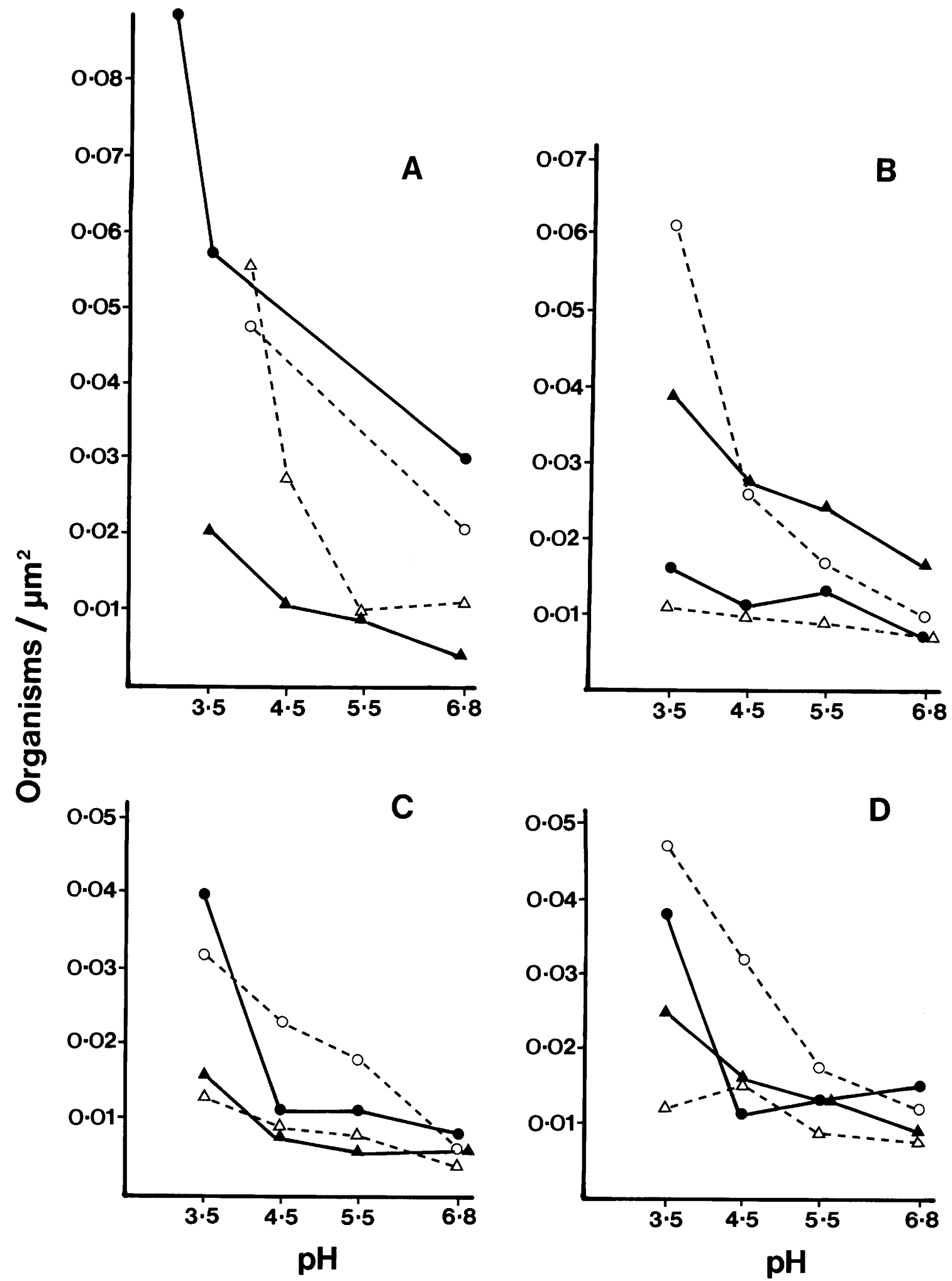

Fig. 2. Effects of $p \mathrm{H}$ and menstrual cycle on adherence of $S$. aureus to vaginal cells. Average number of bacteria per unit area of cell calculated from 20 -cell samples. A $\mathrm{C}=$ Individual results; $\mathrm{D}=$ Mean of results for three subjects. Week of menstrual cycle: $1=\Delta-\Delta$, $2=\Delta-\Delta, 3=\bullet-\bullet, 4=0-0$. 

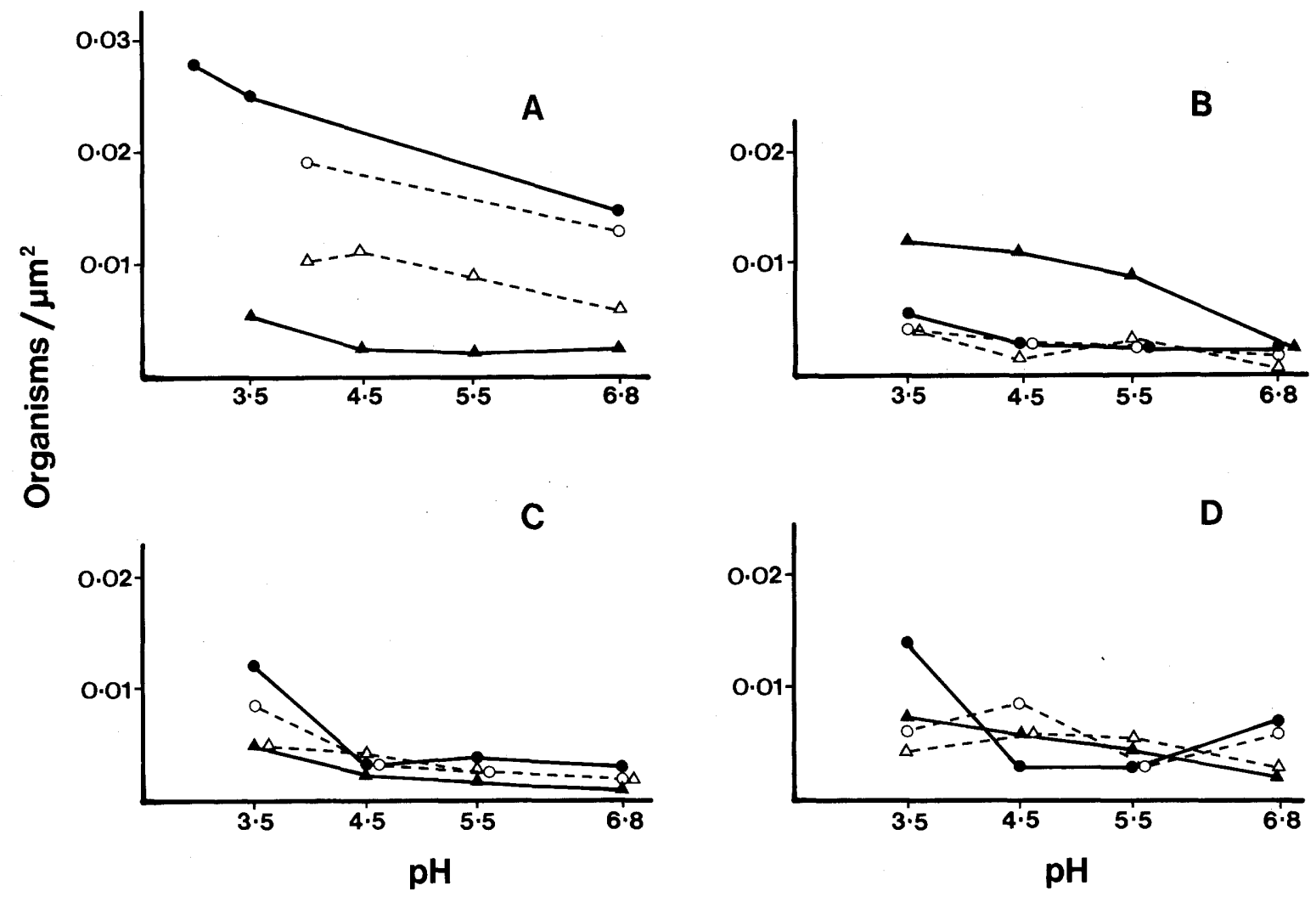

Fig. 3. Effects of $p H$ and menstrual cycle on adherence of $C$. albicans to vaginal cells. Average number of yeast cells per unit area of cell calculated from 20 -cell samples. A-C $=$ Individual results; $D=$ Mean of results for three subjects. Week of menstrual cycle: $1=\Delta-\Delta$, $2=\Delta-\Delta, 3=-, 4=0-0$.

flora of the exterior labia is typically limited to a small variety of gram-positive aerobes (Friedrich, 1976; Aly et al., 1979). Our data demonstrate that the complex ecology of the vulva is also strongly influenced by factors that relate to microbial adherence.

No previous report, to our knowledge, has compared attachment of bacteria and fungi to labial and vaginal cells under standard conditions, although studies with vaginal cells alone have been published. We found that staphylococci and candida cells bind in larger numbers per unit area to the labium majus cells. In contrast to our findings with nasal cells (Aly et al., 1977), P. aeruginosa attached less well than $S$. aureus to labium majus cells.

Vaginal $p \mathrm{H}$ has been correlated with the proportion of specific micro-organisms that colonise its surface (Friedrich, 1976; Galask et al., 1976); $C$. albicans reaches its highest level at around $p \mathrm{H} 4.5$, and lactobacilli dominate at $p \mathrm{H} 4 \cdot 0$. Perhaps the incidence of particular vaginal flora is influenced by the alteration of adherence stemming from changes in hydrogen ion concentration, such as occurs with local electrostatic forces (Ofek and Beachey, 1980).

The increase in bacterial adherence to vaginal cells with acidity has been reported (Mårdh and Weström, 1976; Sobel et al., 1981b), but Botta (1979) found that group B streptococci yielded higher counts at $p \mathrm{H} 7 \cdot 2$ than at $p \mathrm{H} \mathrm{5.4.} \mathrm{Mårdh} \mathrm{and}$ Weström (1976) noticed that different strains of lactobacilli gave variable results. Strain-to-strain variation may similarly explain our finding with $C$. albicans that adherence scores rose with acidity, whereas other workers found otherwise (King et al., 1980; Sobel et al., 1981a).

Over the menstrual cycle, the vaginal $p \mathrm{H}$ of examined volunteers did not change substantially, but the adherence scores of their cells did vary. Although Sobel et al. (1981b) observed no such differences over two menstrual cycles, our results agreed more with those of Botta (1979), who calculated maximal adherence after the second week of menses. However, we found the highest levels after the third week instead and noted more 
profound individual differences. This temporal relationship is reasonable when considering the diverse direct and indirect effects of hormones on cellular biology, including size, maturation, differentiation, and development of receptors. Acquisitions of adherence-interfering or enhancing host secretions may also have an important role.

Our lack of finding differences in adherence of $S$. aureus to labial cells of staphylococcal carriers and non-carriers is contrary to our previous findings with nasal cells (Bibel et al., 1982), and is probably related to the small number of test subjects. The labia are the preferred sites of $S$. aureus in the vulva (Aly et al., 1979; Linnemann et al., 1982); the nasal vestibule is the other favoured site. The higher densities of adherence on nasal and labium majus cells mirrors this enhanced carriage, again demonstrating the importance of adherence in determining host normal flora.

Teichoic acid blocked the receptor for S. aureus on labium majus and vaginal cells in much the same fashion as with nasal cells (Aly et al., 1980; Bibel et al., 1982). This suggests that the cell wall component is the major adhesin of S. aureus for all human epithelial cells, although various host cell receptors may be involved in the interaction (Woods $e t$ al., 1980; Bibel et al., 1982). This last point is supported by the different optimal $p \mathrm{H}$ of staphylococcal adherence on nasal and vaginal cells.

Recently, Rosenstein et al. (1985) pointed out the problem of non-Normal distribution in the analysis of bacterial attachment and challenged the use of

\section{REFERENCES}

Aly R, Britz M B, Maibach H I 1979 Quantitative microbiology of the human vulva. British Journal of Dermatology 101:445-448.

Aly R, Shinefield H R, Litz C, Maibach H I 1980 Role of teichoic acid in the binding of Staphylococcus aureus to nasal epithelial cells. Journal of Infectious Diseases 141:463-465.

Aly R, Shinefield H R, Strauss W G, Maibach H I 1977 Bacterial adherence to nasal mucosal cells. Infection and Immunity 17:546-549.

Bartlett J G, Onderdonk A B, Drude E, Goldstein C, Anderka M, Alpert S, McCormack W M 1977 Quantitative bacteriology of the vaginal flora. Journal of Infectious Diseases 136:271-277.

Beachey E H (ed) 1980 Bacterial adherence, receptors and recognition. Series B, vol. 6. Chapman and Hall, London.

Beachey E H, Simpson W A, Ofek I, Hasty D L, Dale J B, Whitnack E 1983 Attachment of Streptococcus pyogenes to mammalian cells. Reviews of Infectious Diseases 5 Suppl 4:\$670-S677.

Bibel D J, Aly R, Bayles C, Strauss W G, Shinefield H R, Maibach H I 1983 Competitive adherence as a mechanism of bacterial interference. Canadian Journal of Microbiology 29:700-703. the Student $t$ or similar statistical test. We concur with their findings when a heterogeneous cell population is treated homogeneously. Their discussion considered studies in which adherence has been scored as numbers of micro-organisms per cell. However, in our present work and also in some of our earlier reports, we categorised harvested cell populations whenever possible into morphological groups related to cell development, and thereby observed unique adherence characteristics. The distributions were Normal. In our present study we further reduced the problems associated with comparative distributions by analysing adherence not by counts per cell, which may vary with cell size as well as class, but by density. Again, in our studies, distribution appeared Normal. Therefore, in any analysis of microbial adherence, care should be taken to recognise the variety of cells within a host ecosystem. A procedure that takes account of adherent micro-organisms per unit cell area for each cell class should provide more accurate and reproducible data.

Tissue architecture, host secretions, cell maturation and desquamation, hydration, atmosphere, temperature, microbial interactions, and numerous other ecological factors combine to select a vulvar normal flora and form a barrier to colonisation with pathogens. To these factors must be added specific microbial adherence. Our studies have shown that the labial habitats merit consideration in relation to the pathogenesis of vulvar infections.

Bibel D J, Aly R, Shinefield H R, Maibach H I, Strauss W G 1982 Importance of the keratinized epithelial cell in bacterial adherence. Journal of Investigative Dermatology 79:250253.

Botta G A 1979 Hormonal and type-dependent adhesion of group B streptococci to human vaginal cells. Infection and Immunity 25:1084-1086.

Freter R, Jones G W 1983 Models for studying the role of bacterial attachment in virulence and pathogenesis. Reviews of Infectious Diseases 5 Suppl 4:S647-S658.

Friedrich E G, 1976 Vulvar disease. W B Saunders, Philadelphia, $\mathrm{p} 8$.

Galask R P, Larsen B, Ohm M J 1976 Vaginal flora and its role in disease entities. Clinical Obstetrics and Gynecology 19:6181 .

Gibbons R J, Van Houte J 1975 Bacterial adherence in oral microbial ecology. Annual Review of Microbiology 29:1944.

King R D, Lee J C, Morris A L 1980 Adherence of Candida albicans and other Candida species to mucosal epithelial cells. Infection and Immunity 27:667-674.

Linnemann C C et al. 1982 The epidemiology of genital colonization with Staphylococcus aureus. Annals of Internal Medicine 96:940-944.

Mårdh P-A, Weström L 1976 Adherence of bacteria to vaginal epithelial cells. Infection and Immunity 13:661-666. 
Ofek I, Beachey E H 1980 General concepts and principles of bacterial adherence in animals and man. In: Beachey $E \mathrm{H}$ (ed) Bacterial adherence, receptors and recognition. Series $\mathbf{B}$, vol. 6. Chapman and Hall, London, pp 1-29.

Rosenstein I J, Grady D, Hamilton-Miller J M T, Brumfitt W 1985 Relationship between adhesion of Escherichia coli to uro-epithelial cells and the pathogenesis of urinary infection: problems in methodology and analysis. Journal of Medical Microbiology 20:335-344.

Sobel J D, Myers P G, Kaye D, Levison M E 1981 a Adherence of Candida albicans to human vaginal and buccal epithelial cells. Journal of Infectious Diseases 143:76-82.
Sobel J D, Schneider J, Kaye D, Levison M E $1981 b$ Adherence of bacteria to vaginal epithelial cells at various times in the menstrual cycle. Infection and Immunity 32:194-197.

Williamson P, Kligman A M 1965 A new method for the quantitative investigation of cutaneous bacteria. Journal of Investigative Dermatology 45:498-503.

Woods D E, Straus D C, Johanson W G, Berry V K, Bass J A 1980 Role of pili in adherence of Pseudomonas aeruginosa to mammalian buccal epithelial cells. Infection and Immunity 29:1146-1151. 